\title{
Fashion influencers and Instagram. A quasi-perfect binomial
}

\author{
Cristina González Fernández, Freelance journalist specializing in fashion \\ cristina95cgf@gmail.com* \\ Raquel Martínez-Sanz, University of Valladolid, Department of Journalism \\ raquel.martinez.sanz@uva.es \\ *Corresponding author: cristina95cgf@gmail.com
}

\begin{abstract}
Influencers, thanks to their ability to connect with the public, have revolutionized brand communication, making it less invasive and at the same time attractive and dynamic. This research explores the behavior followed by the main Spanish fashion followers, focusing on the strategies and resources used in their communication through Instagram profiles. The gradual incorporation of men into this sector requires identifying whether the publication of habits in this social network vary or not with respect to the author's gender. In addition, compliance with Spanish legislation on advertising is monitored, which obliges the authors to explicitly indicate any message that promotes a product or service from a contractual agreement.
\end{abstract}

\section{Keywords}

influence marketing, instagramer, social networks, brand communication, millennial

\section{Introduction}

Social media 2.0 enables the user to narrate in first person both the consumer experience and the treatment received by the brands. At the same time, and through these tools, the user has the possibility to approach the evaluations provided by their peers. The word of mouth, far from disappearing, has been increased with social media as the circle of confidence of people who no longer have to necessarily be physically close increases ( $\mathrm{Li} \&$ Bernoff, 2011).

If there is a collective especially linked to this way of proceeding, it is the young public, the so-called Millennials (Bolton, Parasuraman, Hoefnagels, Migchels, Kabadayi, Gruber, Loureiro \& Solnet, 2013) who find in the digital space the perfect platform to make known their way of life, their knowledge or opinions on the subject they feel very familiar.

However, only a small percentage of them demonstrate the ability to influence, that is, to generate a reaction in their followers and, consequently, that their recommendations, experiences and opinions are positioned as a preferred option over the rest (Freberg, Graham, McGaughey, \&
Freberg, 2011). This quality, together with the interest that its communication provokes, and which translates into a voluminous community of users, gives rise to what is known as a social influence.

This clear leadership in a large number of young people causes that many commercial brands, and especially those linked to the fashion and beauty sector, find in the profiles of these leaders the perfect showcase to enter, in a non-intrusive way, into the imagination of its target audience and become infected with the credibility and trust that they radiate. Through influence marketing, the conditions that regulate the professional relationship between brand and prescriber are established (Uzunoğlu \& Kip, 2014), making direct reference, among other issues, to actions, times or remuneration. However, the Spanish legislation is clear in this regard, the recipient must be able to distinguish paid messages, and consequently of advertising nature, from those that are not, even if they are signed by individuals (Martínez \& Gaona, 2016).

This research focuses its interest on the fashion industry, one of the most profitable in the world and with the greatest attraction power among young people 
(Ribeiro-Cardoso, Teixeira \& Santos, 2016; Pérez, Clavijo, Luque, \& Pedroni, 2017). In this context, the main objective is to examine how the main fashion influencers in Spain carry out a brand communication in their Instagram accounts, the social media network that has seen its users aged between 16-30 years increase as well as appreciation, especially among women (IAB Spain, 2015; 2016).

If the formula of the social influence is summarized in having a large community of followers and the ability to interfere in the decisions of third parties mainly related to tastes, interests and/or desires (Booth \& Matic, 2011), this work is interested in identifying the strategies developed by these opinion formers (igers ${ }^{1}$ ) aimed at increasing their community and their ability to influence. Likewise, and in a transversal way, it is intended to observe if the communication (themes, language, tone, images, etc.) differs between men and women influencers or if on the contrary there is a homogeneous behavior valid for both genders.

Consequently, the resolution of these objectives invites us to answer the following research questions:

, To what extent do you identify the messages in accordance with the brand (influence marketing) of those which are created through initiative by the fashion prescribers? The purpose is to find out if these opinion former's inform their community of the establishment of a professional link - punctually or continously - with a brand and how it is evidenced.

> How important is the image and text in the influencer's communication through Instagram? Through this question, how the role played by each of these components in this eminently visual social network is valued.

, Are there differences between the techniques employed by fashion prescribing women and their male counterparts when using their Instagram channel? It is about knowing if the communication

1 Iger is used as a synonym of instagramer and refers to the most active users of this social network and way of proceeding of the influencers varies depending on the gender.

\section{The evolution of the influencer phenomenon}

The figure of the social influence is born with the emergence of Web 2.0. The forums were the first digital scenario open to the exchange of opinions but soon the conversation was moved to the blog, a better structured space that cultivated all kinds of themes and interests and that incorporated other expressive possibilities besides the text (Martínez-Sanz, 2013). The variant of the ego-blogger -logbook dedicated exclusively to publicizing the personal experiences carried out by its author- resulted in the advancement of some of the characteristics of younger fashion influencers (Uzunoğlu \& Kip, 2014).

As Gillin (2009) explains, the appearance of Google AdSense in 2003 marked a turning point when introducing the economic and therefore lucrative variable in the activity of blogs. The advertising put under its spotlight the most visited and best positioned blogs, thus initiating the competition of brands by appearing in the most demanded web spaces according to the related themes. The segmentation of the public became a necessity and a clear success factor in any advertising campaign (Rojas \& Redondo, 2017). Blogs also served to relaunch content marketing when they discovered that updated comments, based on the focus of the subject and the concern to cover practical needs of the public, made its author a reference source.

However, it has been the social networks that have taken the influencer phenomenon to its peak, serving as a professional springboard for many young people whose outfits, suggestions and purchases serve as inspiration for the rest (Ribeiro-Cardoso et al., 2016; Colliander \& Marder, 2018). From a commercial point of view it is fully understood that the recommendation from a trustworthy source is a decisive factor when purchasing a product or service (Bigné, Küster, \& Hernández, 2013; Benítez-Eyzaguirre, 2016). In 
Figure 1: Posts of several instagramers with the dress distributed by Lord and Taylor
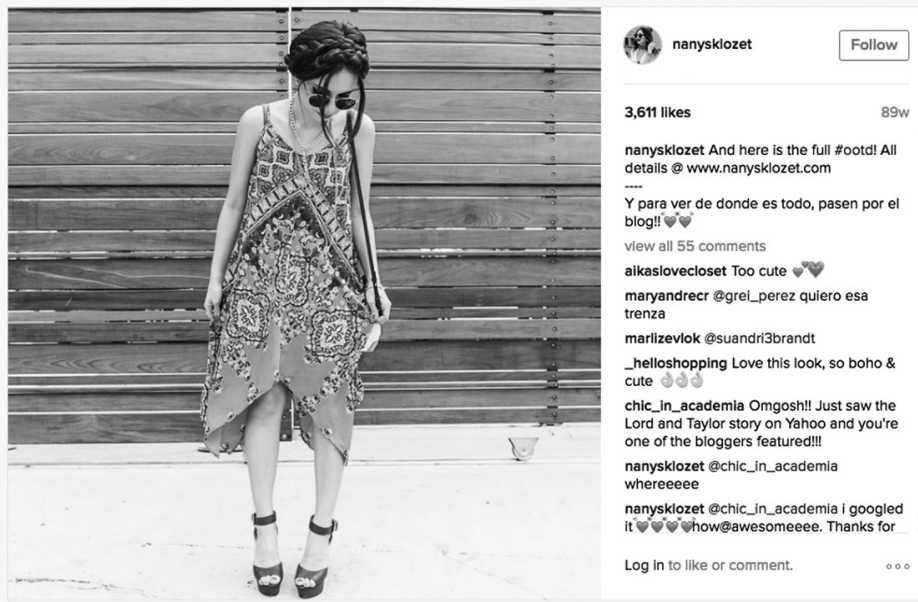

nanysklozet And here is the full \#ootd! All details $@$ www.nanysklozet.com

Y para ver de donde es todo, pasen por el blog!! $\otimes^{\circ} \odot$

view all 55 comments

aikaslovecloset Too cute

maryandrecr @grei_perez quiero esa trenza

marlizevlok @suandri3brandt -helloshopping Love this look, so boho \&

chic_in_academia Omgosh!! Just saw the Lord and Taylor story on Yahoo and you're one of the bloggers featured!!!

nanysklozet @chic_in_academia whereeee

nanysklozet @chic_in_academia I googled it "v" ". Log in to llike or comment.

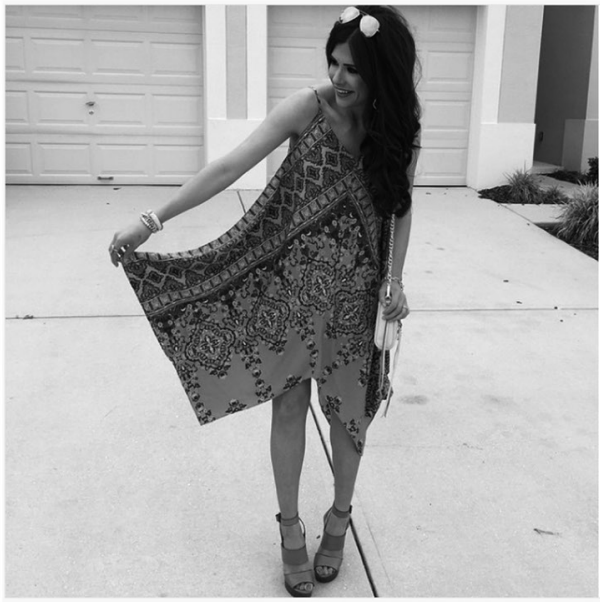

the

emilyanngemma

Follow

8,681 likes

$89 \mathrm{w}$

theemalexander @emilyanngemma I was

looking at this in store yesterday..I may have to buy it now \#instamademedolt ahughes 0309 This pic is on Refinery 29 website. Free dress, good for you! laurencres @cup_cait you would look beautiful in this fa_jewelry@emilyanngemma it is very beautiful tover

kserv09 astephserv it's the dress!l ndoucettexoxo @keghanmeane szabok3 @sujduerr

viviankaro @karolittaaaa @myoshaaaa teestro This dress. @ecdelucia122 mbader522@samcar210

brittney_snyder @shelbyeckert want lizztris@phinguyen0813

Log in to like or comment.

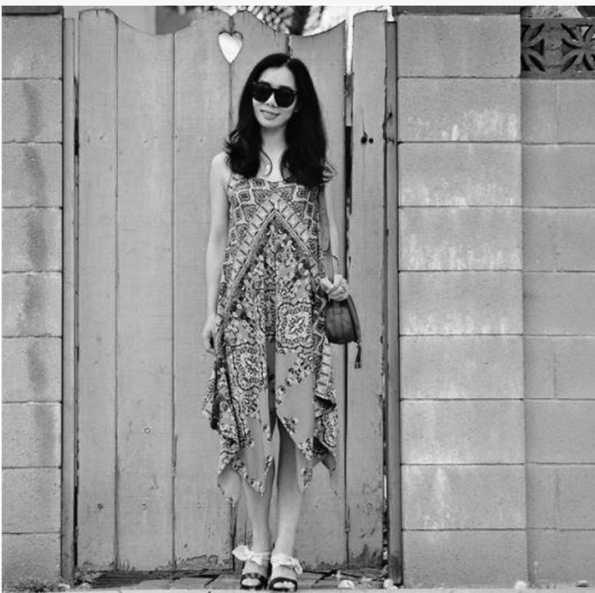

9 halliedaily

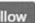

halliedaily Love to stroll the city with beautifu rows blooming everywhere. W Weaning this dresusive to headedoutthedoor Gorgeous dress! qiaoqiao_319 好好看

gr33nfa3 Lovely

dannonkcollardmua Beautifull

pickyyme I love this. So different from your usual style

agoncilloanna :

littleladyhau Saw u on Huffington post!! look amazing all the best for vou beautifull

O

598 likes

MARCH 27, 2015

Add a comment..

Sources: @nanysklozet; @emilyanngemma; @halliedaily 
addition to this, we must add that social networks are not understood without interaction, without the active participation of the recipient. This causes that the consumer can assume at the same time the role of creator, contributing with his reactions to mold the evolution of the brand (Castelló, 2010).

One of the first and most outstanding cases of influence marketing in the field of fashion was launched in 2015, encouraged by the American firm Lord and Taylor (image 1). This brand asked 50 leading instagramers to upload a photo on the same day and at the same time with a particular dress from their new collection, making the garment run out after a few days. With this initiative, the brand achieved that the dress was seen by consumers as a musthave, stimulating them to acquire it. With this example the industry understood that the capacity for conviction is powerfully superior if it comes from a close voice, in which it has trust and may have a trademark despite its advertising efforts.

\section{The attractiveness of the prescriber}

If there is something that characterizes all the influencers, it is their active presence in social media networks, which leads them not to limit their activity to only one, but to expand and adapt their message to the different platforms (Martínez \& Berrocal, 2017). The domain and specialization of each one of them has derived in wellknown users like: instagramers, youtubers, tweeters, etc. to refer to the user generating content of each space.

Likewise, the social influencer is a person with a wide community of followers who trust the information provided by them and to whom they share common interests. With regard to their communication, the possibilities are very varied: from purely informative messages, including recommendations or practical advice, to the story of experiences, lifestyles or opinions. Even the language has a wide range of possibilities: text, photographs, emojis, videos, etc. In short, what is involved is connecting and providing the public with what they are looking for.

The research carried out by Wiedmann, Hennings and Langner (2010) points out the most determining qualities of the profiles that aspire to achieve social influence in the fashion sector.

, Tuning in with users in terms of age, gender and location. Internet users tend to interact and establish social relationships with people with whom they share common characteristics.

, Linked with fashion.

, Specific experience and knowledge.

, Innovative behavior. The appeal in being the first to try, go or experiment and then narrate it in the first person.

, Risky. They do not fear changes and do not place limitations when applied to inflcuening themselves.

A significant percentage of the followers of these opinion formers are young people (IAB, 2016), members of the so-called Millennial Generation (Ruiz Cartagena, 2017). This group, born between 1981 and 2000, does not understand the world without Internet. Moreover, the Web represents one of its main sources of information, in addition to being the main drivers of online consumption. Regarding this McCormick (2016) determines that the millennials associate with each product a brand (burger - McDonalds, cereals - Kellogs, luxury car - Ferrari, etc.) establishing with them a relationship of self-representation and favoring that the brands become an extension of themselves.

However, as Pedro Rojas and María Redondo (2017) have discovered, young people do not talk to brands; they are hardly interested in interacting with them. Hence the need to find other mechanisms for companies to impact their target audiences. To fill this gap, influence marketing has proven to be an effective and profitable tool to generate engagement (Aswani, Ghrera, Kar, \& Chandra, 2017; Castelló \& Pino, 2017). The figures support it: $65 \%$ of fashion professionals say they have carried out actions or campaigns with influencers in 2016 (Launchmetrics, 2017). It is no coincidence that the influencer phe- 
nomenon was born in the midst of an economic crisis, demonstrating that it obtains better results than traditional advertising and at a lower cost, without forgetting the possibility of brands controlling the return on their investment and keeping track of their derived sales.

\section{$4 \quad$ Plan and guide influence in networks}

Influence marketing consists of the contact and link established by a company with influential users of the network-bloggers, instagramers, youtubers, celebrities, etc. Previously identified to multiply the reach of its brand communication. Influencing marketing fuses corporate communication with advertising by extracting the best from each one, in order to ultimately generate a link with the user that ends up making him loyal (Castelló \& Pino, 2015).

In addition, this relationship supposes a mutual benefit for all the parties: while the brand is impregnated with the credibility and confidence radiated by the prescriber, he/she sees thier work rewarded by strengthening his/her position and professional relevance since all the content, of an organic nature - and therefore, not paid-, together with the interaction of the users, contributes to improve the web positioning and with it its visibility. To achieve such optimal results, it is essential that brand and influencer share values and ways of doing and thus provide naturalness to communication. It is about that the effort is channeled towards the same direction and contradictions do not occur.

In most of the occasions, the first encounter with the brand occurs when the company, convinced of the quality of its products or services, is open to impartial people, specialized in the sector, to prove, manipulate and/or experience it. It is not strange, therefore, that many influencers receive free samples or are invited to certain presentations or events in order for them to make a subsequent mention in their networks, transferring to their community of followers the experience, the treatment and / or the impressions experi- enced (Venegas, 2015). The purpose is not only to get a comment that recommends the acquisition of a particular item or complement but to convince the opinion former of the benefits of the brand and, naturally, to become its ambassador.

The professional relationship with the company increases to the next level and adjoins the advertising when the influencer agrees, in exchange for a fee, the type of message to be published, the bias that must be applied to his comment -clearly positive-, and the regularity; all in order to strengthen the attributes of the product. This new status suppresses the freedom of the influencer to make an objective judgment of his opinion. In this regard, Spanish legislation is clear: the recipient must have obvious signs that separate the informative messages from the advertisers; otherwise, misleading advertising occurs (General Advertising Law, 1988, Unfair Competition Law, 1991).

According to Luis Díaz (2017), when advertising agencies contact an influencer to create a campaign, they are sent a brief in which they specify what the brand expects to obtain. Subsequently, everything related to the communication that the influencer must issue is agreed, including the characteristics of the images that will accompany their messages. The depth that can be achieved in the negotiation is such that it can include aspects like the application or not of filters, the aesthetics of the image, the elements that have or not to appear or how to highlight the promoted product. It is usual for the brand to request the explicit mention of its name or the use of a specific hasthag in textual messages. To avoid misunderstandings, the brief can include a section called mood board with illustrative examples that serve as inspiration to influence and ensure the harmony between brand and the prescriber.

\section{Methodology}

If as explained, the influencer tries to build loyalty and expand its community of users through social media, this work aims to analyze the specific techniques 
used by different opinion formers in fashion through their respective Instagram accounts. For this, it has been used the empirical method of investigation called "case-study" (Yin, 2009; Stake, 1995) recommended particulary when the next circunstances happen; attempt to provide and answer for the questions "how" and "why"; the researcher has weak control over the events and when the interest is about a current phenomenom bound with the real life (Yin, 2009). This method, reinforce the explanatory character of it versus the exploratory or descriptive.

The investigation focuses on the study about the publications and interactions achieved by 13 leading Spanish fashion influencers are studied from a quantitative and qualitative point of view. According to the method choosen the tecnique for research is the content analisys technique for the objective posed by its ability to combine observation and data production, with its interpretation (Krippendorff, 2004). To ensure it's rigorness, an analysis template was developed that emphasizes both the visual and textual aspects of the message and the interactions received. The creation of this tool about collecting data has been base on Castelló and Pino's investigation (2015); and Selva and Caro's proyect (2017) and searching posts on Instagram. On this fase we established the most relevant indicators according to the goals and hypothesis showed at the begin- ning of the research and the cathegories of the answers (close/open) that are explained next.

The template was composed of four sections:

, Composition: It is derived from the element the publication is articulated and include three variables: a) type of photography: unpublished, image of file, gif or video; b) at what time of the day the user used Instagram: in the morning, in the afternoon or at night; and c) the day of the week.

, Repercussion: In this section we measure the impact made by each publication and record a) the number of likes and $b$ ) the number of comments received in the first 24 hours is quantified.

, Visual content: Describes the elements that are represented and clarifies how they were captured. In this section, there are nine variables: a) the influencer is identified in terms of presence or absence; b) the condition of the presenter: person, object or landscape; c) the type of plan used: general, medium, selfie, American or detail plan. Next, explain the implications that this type of plane entails; d) how the image is captured: spontaneously or with preparation; e) what the scene reflects: personal moment, state of mind or professional life; f) esthetic: if the composition is careful or careless; g) if commercial brands appear explicitly and which are

Table 1: Main features of the fashion influencers analyzed

\begin{tabular}{|c|c|c|c|c|c|}
\hline Gender & Name & Profile & Followers & Agency & $\begin{array}{l}\text { Publications issued/ } \\
\text { analyzed }\end{array}$ \\
\hline Female & María Turiel & @meryturiel & 391000 & Go Talents & $47 / 14$ \\
\hline Female & Inés Arroyo & @ines_arroyo & 342000 & Okiko Talents & $22 / 9$ \\
\hline Female & María Valdés & @marvaldel & 263000 & Go Talents & $33 / 7$ \\
\hline Male & Luis J. García & @lewisonn & 224000 & Influence Code & $5 / 3$ \\
\hline Female & Marta Soriano & @msorianob & 145000 & Go Talents & $34 / 10$ \\
\hline Male & Alejandro More & @alejandrojamo & 135000 & Influence Code & $12 / 1$ \\
\hline Female & Adriana Boho & @adrianaboho & 115000 & Influgency & $31 / 7$ \\
\hline Female & Marta Vidaurreta & @martavidaurreta & 108000 & Go Talents & $19 / 4$ \\
\hline Male & Aarón Fernández & @aaronfernandezmoda & 74100 & Hamelin & $16 / 5$ \\
\hline Female & Sara Domenech & @saraemdi & 73400 & Influgency & $31 / 6$ \\
\hline Male & Miguel Carrizo & @miguelcarrizo & 39500 & Okiko Talents & $37 / 7$ \\
\hline Male & Gaby Rope & @gabyrope & 31700 & Influgency & $5 / 1$ \\
\hline Male & Fernando Montoya & @montoya_nando & 28500 & Influgency & $18 / 3$ \\
\hline
\end{tabular}


mentioned; h) if labels are integrated within the image and of what type; and i) it is verified if there is explicit allusion to the location and which are the most repeated.

> Textual content: This category monitors the text with five factors: a) the language(s) used is indicated; b) if emojis appear in the configuration of the text message and c) if there is mention of other profiles and what percentage corresponds to brands and which to people; d) quantification and classification of the semantics of the hashtags are quantified and classified and e) checks if the commercial collaborations between brand and influencer are clearly expressed.

Finally, and valuing the message as a whole (image plus text), intentionality is specified.

To carry out the selection of the influencers, three aspects were taken into account: 1. Membership in an influencer agency in Spain 2. Direct and tangible link with the fashion sphere 3 . The volume of their digital community. The selected sample included the two genders: women (54\%) and men (46\%) with a non-parity percentage since the presence of women in the field of fashion prescription is considerably higher. In spite of everything, it is observed that the incorporation of the male gender is progressive. This situation motivates that our study, among other issues, is interested in recognizing if there are strategies of differentiated influence between men and women to connect with the community of followers.

As shown in Table 1, the final sample was constructed as follows:

The study of the profiles took place in the month of April of 2017, analyzing in detail all the messages published along seven non-correlative and random days. To guarantee these premises and, in addition, to avoid coincidences on the day of the week, the selection of the multiples of four days was adopted as a criterion. Consequently, the dates in which the corpus of analysis was collected were the following: April 4 (Tuesday), April 8 (Saturday),
April 12 (Wednesday), April 16 (Sunday), April 20 (Thursday), April 24 (Monday) and April 28 (Friday).

From a total of 311 publications issued by the 13 specialists in April 2017, the study corpus was composed of 77 messages whose impact - number of comments - was recorded 24 hours after being published through screenshots. Reassuring the reliability of the inter-encoders a book about codes has been designed and a preliminary test was done for the measurement of the matches.

\section{Results}

From a quantitative point of view, it is observed that the influencers with the most followers were those who published most of the messages, although it is necessary to clarify that the volume of activity was much higher - almost double - in the profiles of women than men. For them, the average relative to the entire month was 31 entries - one per day - while they published 16 messages per month, which represents approximately one publication every two days.

The messages, in $98.7 \%$ of the cases, were configured by unpublished images, which means prioritizing the photography and the personal style of each author, but at the same time, relegating the experimentation to the rest of the available formats such as videos, gifs or memes, of great social acceptance. Fashion experts choose Sundays and the night time slot as the preferred time to upload content.

With regard to the scope achieved by each publication, although it is true that it is not possible to indicate the number of visualizations obtained, it has been possible to record the number of likes that each message reached in the first 24 hours, confirming that it was not only seen but it was enough of the follower's liking to deserve the gesture of clicking on I like it. The 77 publications received a total of 580503 compliance samples, with @meryturiel being the most acclaimed by far. 
Figure 2: Photography with labels that identify brands
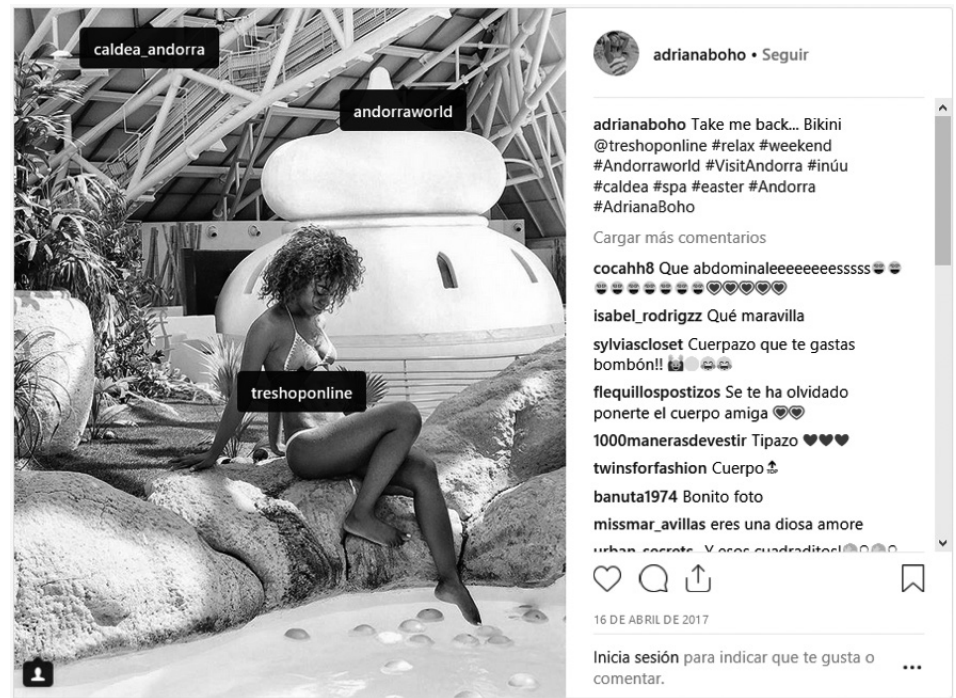

Source:https://www.instagram.com/p/BS8ob9hjsKc/?hl=es\&taken-by=adrianaboho

Table 2: Composition of the title according to the gender of the profile

\begin{tabular}{lcr}
\hline Title & Female profiles & Male profiles \\
\hline Entirely in Spanish & $48.2 \%$ & $50 \%$ \\
With some expressions in English & $5.4 \%$ & $5 \%$ \\
Entirely in English & $34.0 \%$ & $20 \%$ \\
In Spanish and English & $0.0 \%$ & $25 \%$ \\
Composed only of emoji(s) & $12.5 \%$ & $0 \%$ \\
Composed of text and emoticon(s) & $78.6 \%$ & $70 \%$ \\
Includes hashtags & $46.4 \%$ & $90 \%$ \\
\hline
\end{tabular}

\subsection{Visual aspects}

As for the photographs - the central core of the Instagram message - the influencer appears in nine out of ten images. Data that goes down slightly if we only look at the male profiles (85\%). In addition, the prescribers studied appear as absolute protagonists of the image in $88 \%$ of cases. In the other situations, either they share the protagonism or it falls entirely in a landscape or an object. For the latter, the most common are the fashion accessories: wristwatch or sunglasses. In the images in which the influencer was absent, values such as relaxation and calm applied to places or landscapes and qualities such as elegance and comfort for objects were promoted.
The type of plan most commonly used is the general one, identified in half of the images and aimed at showing the full-bodied influencers, allowing them to show their complete looks. In $21 \%$, the plan is of medium type, one of the most used in fashion photography because it discovers up to the waist, allowing seeing the face up close and the upper garment that is worn. In the same proportion (21\%) you opt for the American level that lets you perceive up to your knees, so it is a good option when you want to give importance to accessories such as bags or backpacks. Selfies (self-portraits) only appear in $3 \%$ of the images. This format, which only has room for the representation of the face, barely allows the display of clothes or accessories 
Figure 3: Publication that reinforces the location

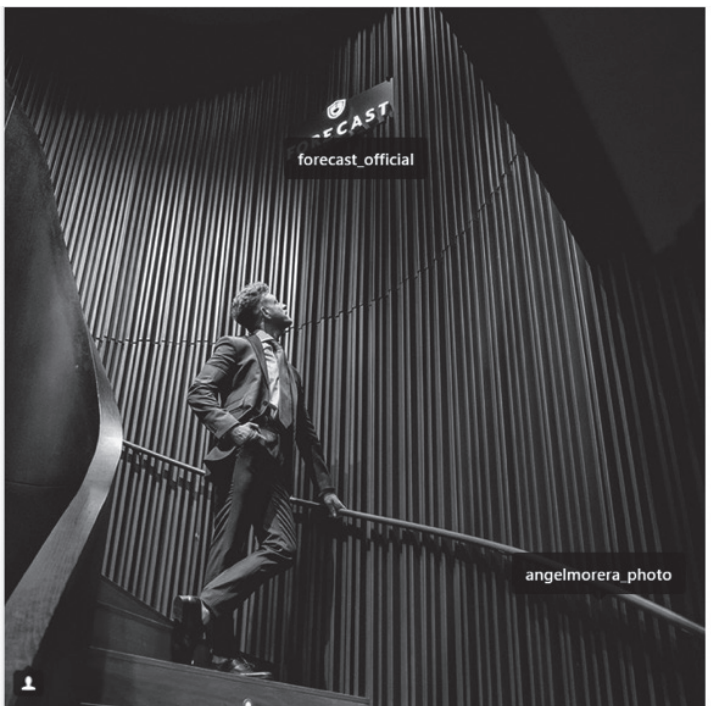

(2) nando_montoya $\cdot$ Seguir

nando_montoya Os invito a que vengáis el 27 de Abril, como os decía, a la tienda de

Nervión de 18:3 0/19:30 o a la tienda de Rioja de 20/21 de @forecast_official Durante esas horas estaré por allí para echaros una mano en lo que deseéis. También podréis gozar de un $20 \%$ de descuento en sus productos. $Y$ no solo eso, además sólo por venir al evento y compartir tu foto con el hashtag

\#confdeforecast podrás entrar en el sorteo de una americana.

forecast_official Muy $₫ @$ @montoya_nando youdecidewhoyouare \& $\odot$ Stay rad! $\odot$ maryou68 Chulada de sitio $\$$ \&

marquissio_com 30 d d

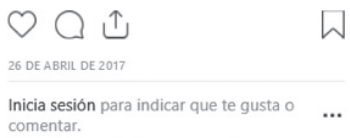

Source: https://www.instagram.com/p/BTWTLy9F-bN/?hl=es\&taken-by=montoya_nando

Figure 4: Repeated mention to a brand that suggests a professional relationship between the parties

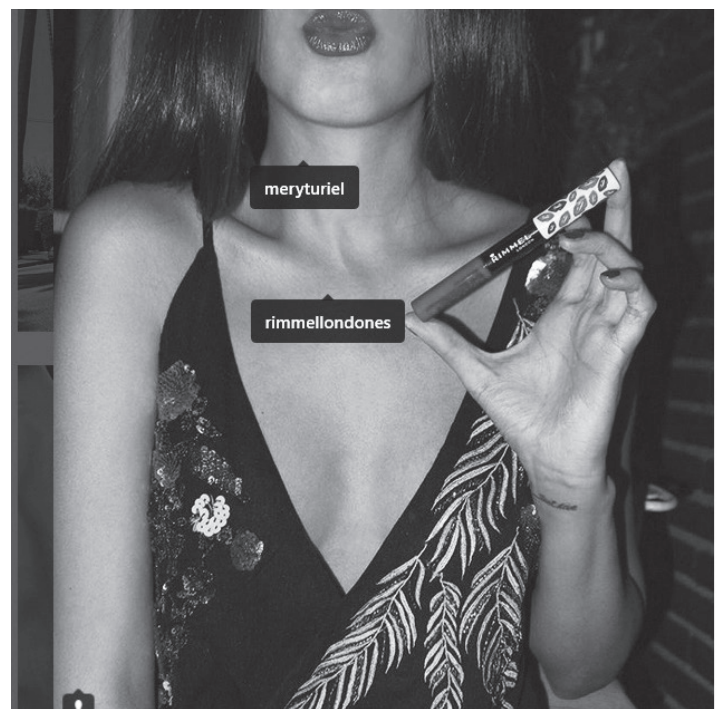

meryturiel $\bullet \cdot$ Segui

Los Angeles, California

meryturiel Una noche de esas que nunca acaba es siempre mejor si tienes el nuevo Provocalips, dura 16 horas, y es súper fácil de poner en dos pasos, para repartir besos sin fin :2.:@RimmelLondonEs \#ProvocaTuLip \#RimmelGirl

Cargar más comentarios

anaalopez31 Hola mery, como se llamaba la aplicacion que es parecida afterlight mariasanchezluna Que chulo el body de donde Es?? ?

23.wihdane El labial lo tengo no vale para nada

isa 1614 Que referencia tiene el body guapa? No sale en la página de zara. Muchas gracias! is

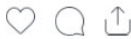

12. DEABPIL DE 2011

Inicia sesión para indicar que te gusta o ...

Source: https://www.instagram.com/p/BSy2VxRACzG/ 
so their use is very residual. The remaining $4 \%$ corresponds to the detail plan used exclusively to show specific objects such as watches or bracelets worn by them.

A feature present in all images, regardless of the gender of its creator, is its evident prior preparation. With the aim of not diverting the Internet user's attention, a good part of the photographs are made on basic backgrounds - generally walls or doors - concentrating the interest in the influencer's outfit. His position tries to convey spontaneity and naturalness, although nothing that appears is casual. In spite of everything, and with a clear intention to connect with the followers, daily and simple situations are staged, linked with the day to day of the young people as an excuse to show what clothes they wear.

Women's profiles abound with photographs that capture personal moments such as makeup, walking or enjoying a drink. The simulated movement of arms or legs and above all, orienting the gaze towards the horizon transmits the sensation of having been captured in full action. In the case of men, the pose is more evident by directing his gaze towards the objective of the camera.

The fact that all the instagramers analyzed are part of a specialized advertising agency allows to deduce that they are interested in the promotion of brands. While it is true that we can not ensure that at the time of the analysis the influencer received a financial consideration for it, it is noticed that most of the publications (82\%), in addition to exhibiting clothes, fashion accessories or physical spaces, they name brands through labels inside the image, to reinforce the message and eliminate any type of doubt about the origin (image 2). It must be recognized that if it does not do so, only in $18 \%$ of the cases would it be possible to recognize who markets the product exhibited through the identification of the isotype, isologo or imagotype representative. For example, the appearance of a polo shirt with a crocodile to automatically associate that garment belongs to the firm Lacoste. Therefore, it is observed that most of the influencers, both men and women, perform a double promotion: visual and textual.

In spite of everything, if there is a common pattern in both genres, it is the care for the staging of their images, even when they do not appear, which is manifested especially in the placement and order of the elements and in the chromatic harmony, being able to get to see images that stand out for their artistic quality.

\subsection{Textual aspects}

Although Instagram is an eminently visual social network, it admits spaces for writing, such as the title of the publication, photography labels and comments.

All publications had their own title: Nearly half $(49.1 \%)$ written entirely in Spanish while $5.2 \%$ also incorporated some Anglo-Saxon expression throughout the message. $27 \%$ was written entirely in English and $12.2 \%$ in both languages, circumstance, the latter, only present in profiles managed by men (table 2 ). In any case, the appearance of a second language gives the profile a more professional and accessible image. In the remaining $6.3 \%$, and present only in the profile of women, the title was composed only by icons. Despite this, it is observed that emojis are a common resource used by influencers of both genders, since in $76.3 \%$ of the messages the presence of at least one is appreciated.

Another valuable resource that Instagram admits in the titles of the publications is to mention another profile - value as an example: "Thank you very much to @ Converse for these shoes" - which allows the user to be redirected to a new space. It is observed that male profiles are more inclined to use it, since it is present in nine out of ten publications, while in women we only find the reference to another account in half of the messages. This feature is used by fashion influencers to redirect commercial brands and, to a lesser extent, personal profiles.

An equally uneven use presents the mention of the location from which the photograph was taken. This information is located in the header, next to the name of the author of the publication and is visible 
in the case of boys in $80 \%$ of their entries, while in the case of girls it does not exceed $18.2 \%$. For the latter, it is evident that the physical space is an accessory element although when it is insinuated it is always to praise it explicitly. Positive bias that also translate male profiles. Circumstance that is one more indication to suppose that a professional relationship has been established. For example, the photo session done by@montoya_nando in the Forecast clothing store.

With regard to intentionality, and taking as a reference the message as a whole, it is observed that the objective of $80 \%$ of the publications of male influencers and $49 \%$ of female publications is to explicitly promote a garment, a fashion space or a product. The way of proceeding in this situation is quite similar in both genders: the article or physical space appears in the image monopolizing the maximum attention while the text does not skimp on flattery including, in addition, the direct mention to the brand by hashtags and / or your Instagram account (image 4 ). In these cases, those closest to the professional link between influencer and brand, there were no explicit signs that confirmed a possible paid collaboration between the two parties. Fact that if proved would be in contravention of Spanish law.

The rest of publications $-20 \%$ for men and $51 \%$ for women influencers - aims to maintain the link with their community of followers by showing their day to day. This circumstance serves as an excuse to describe their outfits and detail, usually through labels, the clothes they carry. In this category there is also room for advice, recommendations or draws: technique that allows to quickly increase the number of followers and the visibility achieved, since, generally, it requires participants to upload an image and label the product.

Seen all this, we can identify that most of the entries published by the influencers on their Instagram profile have a commercial objective aimed at promoting and improving the image of products and brands linked to the field of fashion and / or beauty mainly, although there are also examples linked to leisure, gastronomy and tourism.

\section{Conclusions}

With the aim of delving into the figure of the fashion influencer, this research analyzes the communication resources used by the main Spanish fashion prescribers on Instagram, paying special attention to their use of the image and the text. Likewise, it is investigated in the possible differences between genres and in the fulfillment of the law in matter of Publicity, verifying if the messages include any kind of elements that distinguish the commercial publications - the previously agreed - , of the free and autonomous recommendations of their authors.

The careful observation of the publications of 13 influencers concludes that none of them specified explicitly having a professional relationship with a brand despite identifying behaviours such as the following, which, although they are not unequivocal proof of cooperation, do represent a sign: constant compliments, repeated reference to specific brands and their Instagram profiles, and use of hashtags that either explicitly contained the name of the same brand or had been created by them following the slogan of their last campaign. It was observed that all these procedures converged in the same message in $80 \%$ of the male publications, while the female influencers were more subtle combining the most commercial intentionality with the care of their community of followers present in $51 \%$ of the publications. Purpose, the latter, which materialized through the detailed description of their outfits; the offer of suggestions or advice; or with the announcement of discounts and promotions in certain brands.

They were more prolific during the month analyzed - they published about twice as many messages as their male colleagues - and less interested in identifying the geographical space from which the photographs were taken. Despite these differences, very similar behaviors were identified in both relative genders: the 
concern for the aesthetics of the images and their framing, the prominence of the influencer and their constant presence; and the preference for the Castilian language to express themselves.

The data collected leads to conclude that the predominant purpose of the publications that appear on Instagram by the main fashion influencers in Spain is to promote: publicize and / or improve the image, mainly of clothing, products or fashion accessories by who say they feel sympathy and affinity. The question that remains in the air is whether, at some point, the publications were guided by a prior commercial agreement, because as indicated, there is no clear communication on the part of the influencers despite the evidence found. This situation prevents us from assuring with forcefulness that the law has been broken, which encourages us even more to continue delving into the subject.

\section{References}

Aswani, R., Ghrera, S.P., Kar, A.K., \& Chandra, S. (2017). Identifying buzz in social media: a hybrid approach using artificial bee colony and k-nearest neighbors for outlier detection. Social Network Analysis and Mining, 7(38). doi:10.1007/s13278-0170461-2

Benítez-Eyzaguirre, L. (2016). Analysis of peer recommendations in the online reputation of organizations. El Profesional de la Información, 25(4), 652-660. doi:10.3145/ epi.2016.jul.15

Bigné, E., Küster, I. \& Hernández, A. (2013). Las redes sociales virtuales y las marcas: influencia del intercambio de experiencias eC2C sobre la actitud de los usuarios hacia la marca. Revista Española de Investigación en Marketing ESIC, 17(2), 7-27.

Bolton, R.N., Parasuraman, A., Hoefnagels, A., Migchels, N., Kabadayi, S., Gruber, T., Loureiro, Y.K., \& Solnet, D. (2013). Understanding Generation Y and their use of social media: A review and research agenda. Journal of Service Management, 24 (3), 245-267. doi:10.1108/09564231311326987
Booth, N. \& Matic, J.A. (2011). Mapping and leveraging influencers in social media to shape corporate brand perceptions, Corporate Communications: An International Journal, 16(3), 184-191. doi:10.1108/13563281111156853

Castelló, A. (2010). Estrategias empresariales en la web 2.0, las redes sociales online. Alicante: Editorial Club Universitario.

Castelló, A. \& Pino, C. del (2015). Prescriptores, marcas y tuits: el marketing de influencia. Revista Internacional de Investigación en Comunicación aDResearch ESIC, 12(12), 86-107.

Castelló, A. \& Pino, C. del (2017). La estrategia publicitaria basada en influencers: el caso de smartgirl by samsung. In A. Castelló Martínez y C. del Pino Romero, (Eds.), Publicidad y Convergencia Mediática. Nuevas estrategias de comunicación persuasiva (pp. 116-146). Sevilla, España: Egregius.

Colliander, J. \& Marder, B. (2018). 'Snap happy' brands: Increasing publicity effectiveness through a snapshot aesthetic when marketing a brand on Instagram. Computers in Human Behavior, 78, 34-43. doi:10.1016/j. chb.2017.09.015

Díaz, L. (2017). Soy marca: quiero trabajar con influencers. Barcelona: Profit Editorial.

Freberg, K., Graham, K., McGaughey, K. \& Freberg, L.A. (2011). Who are the social media influencers? A study of public perceptions of personality. Public Relations Review, 37(1), 90-92. doi:10.1016/j. pubrev.2010.11.001

Gillin, P. (2009). Los nuevos influyentes. Madrid: LID Editorial.

IAB SPAIN. Interactive Advertising Bureau Spain (2015). VI Estudio anual de redes sociales. Madrid: IAB Spain.

www.iabspain.net/ wp-content/.../2015/01/Estudio_Anual_ Redes_Sociales_2015.pdf

IAB SPAIN. Interactive Advertising Bureau Spain (2016). Estudio anual de redes sociales. Madrid: IAB Spain. www.iabspain.es/ wp-content/uploads/iab_estudioredessociales_2017_vreducida.pdf

Krippendorff, K. (2004). Content Analysis: An Introduction to Its Methodology. California: SAGE.

Launchmetrics (2017). Informe sobre el estatus del marketing de Influencers 2017. 
https:/ / www.launchmetrics.com/es/ recursos/whitepapers/informe-marketing-influencers-2017

Law 3/1991, de 10 de enero, de Competencia Desleal, BOE núm. 10, pp. 959-962.

Law 34/1988, de 15 de noviembre, General de Publicidad, BOE núm. 274, pp. 3246432467.

Li, C. \& Bernoff, J. (2008). Groundswell: Winning in a World Transformed by Social Technologies. Boston: Harvard Business Press.

Martínez Pastor, E. \& Gaona Pisonero, C. (2016). Límites jurídicos de la publicidad en redes sociales: Facebook, Instagram y Twitter. In C. Mateos Martín \& F. J. Herrero Gutiérrez (Eds.), La Pantalla Insomne (pp. 2410-2421). Santa Cruz de Tenerife, Spain: Cuadernos artesanos de Comunicación.

Martínez-Sanz, R. (2013). El blog a las puertas del museo, pero ¿por qué no entra? El caso de los centros de arte contemporáneo en España. Revista Telos. Cuadernos de Comunicación e Innovación, 95, 108-115.

Martínez, R. \& Berrocal, S. (2017). Museos y engagement. La calidad de los espacios web como soporte del compromiso. Revista Española de Documentación Científica, 40(1), e166. doi:10.3989/redc.2017.1.1383

McCormick, K. (2016). Celebrity endorsements: influence of a product-endorser match on Millennials attitudes and purchase intentions. Journal of Retailing and Consumer Services, 32, 39-45.

Pérez, C., Clavijo, L., Luque, S. \& Pedroni, M. (2017). Social Media y Comunicación Corporativa. Nuevo reto en las empresas de Moda. In J. Herrero (Coord.), Del verbo al bit (pp. 2029-2059). La Laguna, Spain: Sociedad Latina de Comunicación Social. Ribeiro-Cardoso, P., Teixeira, S., \& Santos, A. N. (2016). Liderazgo de opinión de moda, adhesión a la innovación y actitud hacia la publicidad entre los consumidores portugueses. Revista Mediterránea de Comunicación, 7(2), 101-115. doi:10.14198/ MEDCOM2016.7.2.12

Rojas, P. \& Redondo, M. (2017). Cómo monetizar las redes sociales. Madrid: LID Editorial.

Ruiz Cartagena, J. J. (2017). Millennials y redes sociales: estrategias para una comunicación de marca efectiva. Revista Miguel
Hernández Communication Journal, 12(8), 347-367. doi:10.21134/mhcj.v0i8.196

Selva, D. \& Caro, L. (2017). Uso de Instagram como medio de comunicación política por parte de los diputados españoles: la estrategia de humanización en la "vieja" y la "nueva” política. El profesional de la información, 26(5), 903-915. doi:10.3145/ epi.2017.sep.12

Stake, R. E. (1995). The art of case study research. London: SAGE.

Uzunoğlu, E. \& Kip, S. (2014). Brand communication through digital influencers: Leveraging blogger engagement. International Journal of Information Management, 34(5), pp. 592-602. doi:10.1016/j.ijinfomgt.2014.04.007

Venegas, A. (2015). Marcas Vs «Influencers»: matrimonio de conveniencia. Agencias y "Blogueras" ofrecen sus puntos de vista sobre el estado actual del marketing de influencia. Revista Anuncios: Semanario de publicidad y marketing, 1516, 20-24.

Wiedmann, K. P., Hennings, N. \& Langner, S. (2010). Spreading the word of fashion: Identifying social influencers in fashion marketing. Journal of Global Fashion Marketing: Bridging Fashion and Marketing, 1(3), 142-153. doi:10.1080/20932685.2010. 10593066

Yin, R. K. (2009). Case Study Research. Design and Methods. Applied Social Research Methods. (6th edition). California: SAGE. 
